\title{
Avian species richness in cities: A review of the Spanish-language literature from the Southern Cone of South America
}

\section{Catalina B. Muñoz-Pacheco}

Universidad de Chile

Nelida R. Villasenor ( $\square$ nvillasenor@gmail.com )

Universidad de Chile https://orcid.org/0000-0001-8624-4484

\section{Research Article}

Keywords: Argentina, birds, Chile, species richness, urban parks, Uruguay.

Posted Date: February 25th, 2021

DOl: https://doi.org/10.21203/rs.3.rs-157419/v1

License: (c) (1) This work is licensed under a Creative Commons Attribution 4.0 International License.

Read Full License

Version of Record: A version of this preprint was published at Urban Ecosystems on October 19th, 2021. See the published version at https://doi.org/10.1007/s11252-021-01180-w. 


\section{Abstract}

South America sustains an important part of the world's terrestrial biodiversity and presents a high urbanization level. Global syntheses have revealed a paucity of urban ecological research in this region; however, local research might be overlooked due to language barriers. To contribute to disseminate local knowledge, we synthesized the Spanish-language literature on bird species richness in the Southern Cone of South America - an area of high diversity, endemism, and more than half of the world's terrestrial biomes. In this systematic review, we identified patterns and trends in the literature, and the variables that influence bird species richness. Most research was performed in large cities, focused on green areas (large urban parks), short-termed (1 year or less) and involved one season only (reproductive). The most studied biomes were Temperate grasslands, savannas and shrublands, and Mediterranean and Temperate forests, and no study was found in mountains or deserts. Bird species richness in cities from the Southern Cone was positively influenced by vegetation cover and plant and habitat diversity; whereas variables associated with urban cover and disturbance exhibited negative effects. Important gaps of knowledge include research in small and medium size cities, in overlooked biomes (desserts, xeric shrublands, montane grasslands and shrublands), long-term research, comprising different seasons, including green space other than urban parks, and interdisciplinary studies that consider environmental, social, and economic components of urban ecosystems. By filling these key knowledge gaps, researchers from South America can contribute to the development of science-based actions to preserve nature in an urbanizing world.

\section{Introduction}

The field of urban ecology has experienced a rapid growth in the last few decades. Most of the research has emerged from developed countries, especially in temperate regions of the northern hemisphere (US, Canada y Western Europe; Magle et al. 2012; Escobar-lbáñez \& MacGregor-Fors 2017). However, the main future urban growth will occur in Latin America, Africa and Asia (United Nations 2019). The paucity of urban ecological research in these continents has led to an important knowledge gap that limits sustainable urban development (Ortega-Álvarez \& MacGregor-Fors 2011a; Magle et al. 2012).

Latin America is one of the most urbanized regions in the world. In the last 70 years, human urban population exhibited ca. 8-fold increase (United Nations 2019). Currently, about $80 \%$ of the human population live in urban areas, and human population in large cities is expected to further increase a $15 \%$ by 2030 (United Nations 2015). Urbanization has dramatically transformed landscapes, creating ecosystems that are dominated by impervious surfaces (Garaffa et al. 2009). This leads to the loss and fragmentation of habitats for different species that cannot cope with the rapid change of land (Grimm et al. 2008). Given the rapid decline of global biodiversity, it is important to promote urban ecological research to provide evidence-based knowledge and help conserve biodiversity under increasing urbanization. 
Encouraging urban ecological research in South America will help preserve its large natural capital. This region contains more than $40 \%$ of the Earth's biodiversity, including $70 \%$ percent of vertebrate species in the world, and more than $25 \%$ of forests (UNDP 2010). It contains $70 \%$ of global terrestrial ecoregions and biomes, comprising a large variety of the world's plants and animals (Olson et al. 2001). In addition, the region presents five of 35 biodiversity hotspots where conservation actions should be prioritized as they contain high endemism in plants and animals but lost more than $70 \%$ of the original vegetation (Mittermeier et al. 2011).

The Southern Cone of South America is characterized by endemic species and evolutionary novelties (Ibarguchi 2014). It comprises three countries: Argentina, Chile, and Uruguay. Chile exhibits high endemism, where ca. $25 \%$ of the species are endemic to the country (MMA 2018). Argentina has three environments with the greatest species diversity in South America (the Paranaense jungle, the Yungas and the Chaco) (SAyDS 2015). In Uruguay, 35\% of the species have been declared a priority species, with several populations facing a high level of threat (MVOTMA, 2014). The region not only presents many endemic birds, mammals and reptiles, but also maintains several species threatened with extinction. For instance, 38 threatened animal species inhabit in the Patagonian Steppe and 40 threatened animal species inhabit in the Valdivian temperate forests (Hoekstra et al. 2010). In addition, this region can contribute to a better understanding on biodiversity responses to urbanization in different climates and geological conditions because it presents more than half of world's terrestrial biomes (eight of 15 biomes, Henwood 1998).

Previous syntheses of urban ecological research have found either no studies or a few studies from Chile and Uruguay, whereas Argentina contributes with an important proportion of studies from Latin America (Ortega-Álvarez \& MacGregor-Fors 2011a; Beninde et al. 2015; Escobar-lbáñez \& MacGregor-Fors 2017). However, these results might be limited by the search language, where languages other than English are commonly overlooked in scientific reviews. Spanish is the second most widely spoken native language on the planet (after Mandarin Chinese), and it is important for disseminating local knowledge because it is the main language spoken in the region and several Latin American journals publish articles in Spanish, including ca. 40 ISI-indexed journals in the field of ecology and zoology (Neira et al. 2011). In addition, people from countries where the official language is other than English are less likely to read and publish in English (Nuñez et al. 2019).

To help disseminate findings from urban ecological research from Latin America, we synthesized the state of knowledge on bird species richness in the Southern Cone (Chile, Argentina y Uruguay). We focused on birds because they are one of the most studied animal groups and are commonly used to study biodiversity patterns in urban ecosystems (McKinney 2008). They are diverse, form complex communities, respond to changes in habitat conditions, and can be used as bioindicators (MacGregorFors \& Escobar-lbáñez 2017, Chace \& Walsh 2006).

We focused on the Spanish-language literature, as this information has been commonly excluded from both global and regional reviews. We evaluated: (1) publication trends and geographical patterns, (2) 
study designs, (3) the origin of the species considered in analyses of bird species richness, and (4) effects of predictive variables on bird species richness. We discuss our findings in the context of urban ecological research and identify knowledge gaps to encourage the development of the field in the region and their global impact.

\section{Methods}

\section{Search strategy}

We searched for relevant papers on Google Scholar (https://www.scholar.google.com), with help of publish or perish software (Harzing 2010). We used Google Scholar because it contains papers from any language and contains a larger number of documents in Spanish than other search engines (e.g. Web of Science or Scopus). In addition, it contains peer-reviewed articles in indexed journals as well as grey literature (e.g. papers published in non-idexed journals, conference papers, thesis and reports) (Falagas et al. 2008). We included grey literature because it represents a large body of knowledge that it is recommended to be considered in systematic reviews (Manterola et al. 2013). Grey literature also reduces publication bias because non-concluding results or those that are contrary to common findings are less likely to be published (González et al. 2011).

The search was conducted on July 24th 2020. As recommended by Pullin and Stewart (2006), we aimed for high sensitivity. Thus, our search included the following combination of keywords in Spanish: "species richness" AND birds AND city AND (Chile OR Argentina OR Uruguay). The word birds (aves in Spanish) was considered in the title. Titles and abstracts identified in the search were scrutinized and the entire article was retrieved when likely to fulfil the following inclusion criteria: (1) it reported empirical data on bird species richness, (2) was located in cities from the Southern Cone (i.e. Argentina, Chile or Uruguay), and (3) was written in Spanish. For all papers that met the inclusion criteria, the list of references was read searching for new relevant documents (not found by the search engine).

\section{Data extraction and synthesis}

For each article that met our inclusion criteria, we extracted information that allowed us to evaluate:

(1) Publication trends and geographical patterns: we extracted the year the study was published, publication type (if published in a scientific journal we extracted the journal name), country and city where the investigation took place. To identify the biomes that have received more and less attention, we located cities on a digital layer (shapefile) of the word's terrestrial biomes (Albers 2019), and calculated the number of cities with and without studies per biome.

(2) Study designs: we extracted study extent (in years), season when sampling was performed, and the environments or land use types where sampling took place.

(3) Bird species richness: we recorded the origin of the species included in analyses of species richness (i.e. native, exotic and both). 
(4) Effects of predictive variables on species richness: we recorded the independent variables studied and their effects on (or associations with) bird species richness. The effect of independent variables on species richness was classified as positive when a positive coefficient was statistically significant $(P<$ $0.05)$, negative when a negative coefficient was statistically significant $(P<0.05)$, and $(3)$ neutral when no statistical differences was found $(P>0.05)$.

We performed a qualitative synthesis and assessment, following synthesis in urban biodiversity research (e.g. McKinney 2002; Farinha-Marques et al. 2011, Nielsen et al. 2014).

\section{Results}

We found 497 documents in our search in Google Scholar. Four of these were duplicated records. From the list of references, another 20 documents were included that were not detected in our original search. After reading the title and abstract of the 513 records, 206 entire documents were assessed. Of these, 30 studies met our inclusion criteria and were included in our qualitative synthesis (Fig. 1). The other 176 documents were excluded because they did not meet our inclusion criteria: 115 studies did not present empirical data on species richness, 45 articles were not in a city (nor town), and 16 did not take place in the Southern Cone.

\section{Publication trends and geographical patterns}

Among the 30 documents that met our inclusion criteria, only two studies ( $7 \%$ of total) were published between 1980 and 1999, whereas 16 studies (50\%) were published between 2000-2009, and 12 studies (40\%) were published between 2010-2019 (Fig. 2A). No studies were found in 2020. Most studies (70\%) were published in scientific journals, followed by book Chaps. (10\%) and theses (10\%, Fig. 2B). Among journals, most studies were published in The Chilean Bulletin of Ornithology ( $27 \%$ of total, Boletín Chileno de Ornitología that since 2016 is published under the name of Revista Chilena de Ornitología) followed by El Hornero (18\%, published by the Argentinian Birds/La Plata Ornithological Association, Fig. 2C).

Fifteen studies (50\% of total) were conducted in Argentina, 14 (47\%) in Chile, and one (3\%) in Uruguay. They comprised 14 cities, with most of the studies being conducted in the capital city of Chile (Santiago, 7 studies, 23\%) and Argentina (Buenos Aires, 6 studies, 20\%) (Fig. 3A). All studies comprised a single city, except for one that included two different cities (Díaz et al. 2018 in Table 1). 
Table 1

Summary table of the 30 publications included in qualitative synthesis (references can be found in Appendix).

\begin{tabular}{|c|c|c|c|}
\hline Author & Country & City & Biome \\
\hline $\begin{array}{l}\text { Faggi \& } \\
\text { Perepelizin, } \\
2006\end{array}$ & Argentina & $\begin{array}{l}\text { Buenos } \\
\text { Aires }\end{array}$ & Temperate Grasslands, Savannas and Shrublands \\
\hline $\begin{array}{l}\text { Perepelizin \& } \\
\text { Faggi, } 2009\end{array}$ & Argentina & $\begin{array}{l}\text { Buenos } \\
\text { Aires }\end{array}$ & Temperate Grasslands, Savannas and Shrublands \\
\hline $\begin{array}{l}\text { Díaz \& Armesto, } \\
2003\end{array}$ & Chile & Santiago & Mediterranean Forests, Woodlands and Scrub \\
\hline $\begin{array}{l}\text { Cursach \& Rau, } \\
2008 \text { a }\end{array}$ & Chile & $\begin{array}{l}\text { Puerto } \\
\text { Montt }\end{array}$ & Temperate Broadleaf and Mixed Forests \\
\hline $\begin{array}{l}\text { Cavicchia \& } \\
\text { García, } 2012\end{array}$ & Argentina & $\begin{array}{l}\text { Buenos } \\
\text { Aires }\end{array}$ & Temperate Grasslands, Savannas and Shrublands \\
\hline $\begin{array}{l}\text { Juri \& Chani, } \\
2009\end{array}$ & Argentina & $\begin{array}{l}\text { San Miguel } \\
\text { de Tucumán }\end{array}$ & Tropical Moist Broadleaf Forests \\
\hline $\begin{array}{l}\text { Mella \& Loutit, } \\
2007\end{array}$ & Chile & Santiago & Mediterranean Forests, Woodlands and Scrub \\
\hline Soto, 2014 & Chile & Concepción & Temperate Broadleaf and Mixed Forests \\
\hline Krauczuk, 2006 & Argentina & Posadas & Flooded Grasslands and Savannas \\
\hline $\begin{array}{l}\text { Muñoz et al. } \\
2018\end{array}$ & Chile & Santiago & Mediterranean Forests, Woodlands and Scrub \\
\hline Figini, 2019 & Argentina & Mendoza & Temperate Grasslands, Savannas and Shrublands \\
\hline $\begin{array}{l}\text { Chávez- } \\
\text { Villavicencio, } \\
2018\end{array}$ & Chile & Coquimbo & Mediterranean Forests, Woodlands and Scrub \\
\hline $\begin{array}{l}\text { Rodríguez et al. } \\
2016\end{array}$ & Chile & Coquimbo & Mediterranean Forests, Woodlands and Scrub \\
\hline Estades, 1995 & Chile & Santiago & Mediterranean Forests, Woodlands and Scrub \\
\hline $\begin{array}{l}\text { Urquiza \& Mella, } \\
2002\end{array}$ & Chile & Santiago & Mediterranean Forests, Woodlands and Scrub \\
\hline Feninger, 1983 & Argentina & $\begin{array}{l}\text { Buenos } \\
\text { Aires }\end{array}$ & Temperate Grasslands, Savannas and Shrublands \\
\hline $\begin{array}{l}\text { Leveau \& } \\
\text { Leveau, } 2004\end{array}$ & Argentina & $\begin{array}{l}\text { Mar del } \\
\text { Plata }\end{array}$ & Temperate Grasslands, Savannas and Shrublands \\
\hline Díaz et al. 2018 & Chile & $\begin{array}{l}\text { Valdivia and } \\
\text { Santiago }\end{array}$ & $\begin{array}{l}\text { Temperate Broadleaf and Mixed Forests; and } \\
\text { Mediterranean Forests, Woodlands and Scrub }\end{array}$ \\
\hline
\end{tabular}




\begin{tabular}{|c|c|c|c|}
\hline Author & Country & City & Biome \\
\hline $\begin{array}{l}\text { Cursach \& Rau, } \\
2008 b\end{array}$ & Chile & Osorno & Temperate Broadleaf and Mixed Forests \\
\hline $\begin{array}{l}\text { Hinojosa-Sáez } \\
\text { et al. } 2007\end{array}$ & Chile & Concepción & Temperate Broadleaf and Mixed Forests \\
\hline $\begin{array}{l}\text { Juri \& Chani, } \\
2005\end{array}$ & Argentina & $\begin{array}{l}\text { San Miguel } \\
\text { de Tucumán }\end{array}$ & Tropical Moist Broadleaf Forests \\
\hline $\begin{array}{l}\text { Kusch et al. } \\
2008\end{array}$ & Chile & $\begin{array}{l}\text { Punta } \\
\text { Arenas }\end{array}$ & Temperate Broadleaf and Mixed Forests \\
\hline $\begin{array}{l}\text { Fernández et al. } \\
2009\end{array}$ & Argentina & $\begin{array}{l}\text { San Miguel } \\
\text { de Tucumán }\end{array}$ & Tropical Moist Broadleaf Forests \\
\hline $\begin{array}{l}\text { Leveau \& } \\
\text { Leveau, } 2006\end{array}$ & Argentina & $\begin{array}{l}\text { Buenos } \\
\text { Aires }\end{array}$ & Temperate Grasslands, Savannas and Shrublands \\
\hline $\begin{array}{l}\text { Germain et al. } \\
2008\end{array}$ & Argentina & $\begin{array}{l}\text { Buenos } \\
\text { Aires }\end{array}$ & Temperate Grasslands, Savannas and Shrublands \\
\hline $\begin{array}{l}\text { Haedo et al. } \\
2010\end{array}$ & Argentina & $\begin{array}{l}\text { San Miguel } \\
\text { de Tucumán }\end{array}$ & Tropical Moist Broadleaf Forests \\
\hline $\begin{array}{l}\text { Seguí \& } \\
\text { Caballero-Sadi, } \\
2013\end{array}$ & Uruguay & Montevideo & Tropical Grasslands, Savannas and Shrublands \\
\hline Leveau, 2012 & Argentina & $\begin{array}{l}\text { Mar del } \\
\text { Plata }\end{array}$ & Temperate Grasslands, Savannas and Shrublands \\
\hline $\begin{array}{l}\text { Ramírez et al. } \\
2016\end{array}$ & Argentina & Luján & Temperate Grasslands, Savannas and Shrublands \\
\hline Chiang, 2019 & Chile & Santiago & Mediterranean Forests, Woodlands and Scrub \\
\hline
\end{tabular}

Regarding the biomes, $57 \%$ of cities studied were in forests and $43 \%$ in grasslands (Fig. 3B). No study was found in cities located in montane grasslands and shrublands neither in desert and xeric shrublands. Most studies (51\%) were in temperate zones. Most studies were performed in "Temperate Grasslands, Savannas and Shrublands" (32\%), "Mediterranean Forests, Woodlands and Scrub" (29\%) and "Temperate Broadleaf and Mixed Forests" (19\%) (Fig. 4A). All biomes found in the Southern Cone present several cities where research on bird species richness have not been conducted. Only the biome "Montane Grasslands and Shrublands" contains a single city (Putre, Chile), where no study on bird species richness was found (Fig. 4B).

\section{Study design}

Regarding the temporal length, 22 studies $(71 \%)$ were performed in a year or less, whereas only two studies (6\%) comprised surveys longer than two years (Fig. 5A). Sampling was conducted in spring- 
summer season in $52 \%$ of the studies, $16 \%$ was performed in autumn-winter season, and $26 \%$ included four seasons (Fig. 5B).

Most studies (58\%) focused only in one environment, where green areas were the most frequent (39\% of studies focused only in these areas). They were followed by sampling in two environments (29\%) and along an urban gradient (13\%) (Fig. 5C). Among the studies that surveyed green areas, the most common were large urban parks, followed by small parks, hills and only one study in vacant lands (Fig. 5D).

\section{Bird species richness}

To calculate bird species richness, both native and exotic birds were pulled together in $77 \%$ of the studies. Four studies (13\%) analyzed species richness for native birds only; whereas only two studies (7\%) analyzed bird species richness of native and exotic birds separately (Perepelizin \& Faggi, 2009; Chiang, 2019; Fig. 6A).

\section{Effect of predictive variables on species richness}

Twenty studies evaluated relationships between bird species richness and independent variables. Most studies (52\%) investigated environmental variables: 10 studies included vegetation variables and 8 included land use (Fig. 6B). Other variables considered were bird attributes (e.g. home range, biological traits, feeding, resting and nesting substrate), season and human-related variables (e.g. vehicle traffic, transit of people, population density and knowledge on birds), but socioeconomics has not been investigated. Ten studies conducted statistical analyses to evaluate the effect of independent variables on species richness, where we obtained 27 relationships (presented $P$-values). Most studies found a positive influence on bird species richness of vegetation cover (e.g. percent cover of different vegetation layers, Normalized Difference Vegetation Index [NDVI]), plant diversity (e.g. diversity of trees and native plants) and habitat diversity (diversity of land cover types) (Fig. 6C). In contrast, urban cover (e.g. percent cover of built-up, pavement and residential areas) and urban disturbance (e.g. human and vehicle traffic) exhibited mostly negative effects on bird species richness.

\section{Discussion}

\section{Publication trends and geographical patterns}

In contrast to reviews on bird species richness that commonly report a null contribution of studies from the Southern Cone of South America (e.g. Marzluff et al. 2001; Aronson et al. 2014; Nielsen et al. 2014), we found thirty studies written in Spanish that investigated bird species richness in cities. Only two studies were published before 2000, which is consistent with the time-lag in the development of urban ecological research experienced by Latin American countries (Ortega-Álvarez \& MacGregor-Fors 2011b). Although the number of articles increased in 2000-2009 period, they dropped in the last decade (20102019). The decline of studies published in Spanish language might be due to increasing pressures for publishing in English at international peer-reviewed journals among local scientists. For instance, a review 
on Ortega-Álvarez \& MacGregor-Fors (2011b) found a dramatic increase in the number of publications written in English from Latin American countries since 2005, which might explain the observed recent decline of publications in the local language.

As pressures for publishing in international journals continue in Latin America, the science-policy gap might increase over time. Our findings show that most studies are published in academic journals, where those led by Ornithological Associations of Chile (Boletín/Revista Chilena de Ornitología) and Argentina (El Hornero) are important in disseminating knowledge that is accessible to managers, planners, policy makers and citizens - at least the work is available in the official language and it is free (open-access). This finding highlights that scientific associations from these countries could play an important role in assist managers and urban planners to promote biodiversity conservation and sustainable urban development.

Chile and Argentina contributed with a similar number of publications. This result disagrees with findings from previous reviews focused on urban birds in Latin America, where the number of publications from Argentina commonly outperforms the number of publications from Chile. For instance, in a literature review on bird community diversity, composition and spatial distribution, the number of studies was 7fold larger in Argentina than in Chile (Ortega-Álvarez \& MacGregor-Fors, 2011a). In addition, OrtegaÁlvarez \& MacGregor-Fors (2011b) found five-fold more bird studies (including bird species lists, ecology and conservation) in Argentina than in Chile. MacGregor-Fors \& García-Arroyo (2017), reported that the number of studies on bird species richness and composition in Argentina doubled the number of studies from Chile. Leveau \& Zuria (2017) found the double of studies on bird demography and population dynamics in Argentina compared to Chile. The difference between our finding and previous reviews can be explained by the late development of the discipline of urban ecology in Chile, where only recently urban bird studies from Chile are increasing in international peer-reviewed journals (e.g. Silva et al. 2015, Celis-Diez et al. 2017, Muñoz-Pedreros et al. 2018, Amaya-Espinel et al. 2019, Villaseñor \& Escobar 2019, Villaseñor et al. 2020).

Avian ecological research in Latin America focuses on large cities (Escobar-Ibáñez \& MacGregor-Fors, 2017). Our review evidence that almost half of bird studies from the Southern Cone of South America are focused on capital cities: Santiago de Chile, Buenos Aires and Montevideo. In fact, the only study found in Uruguay was conducted in its capital (Montevideo). Although it is important to generate scientific evidence in large cities, it is also relevant to study smaller urban areas, which are likely to experience rapid and unplanned urban growth. Scientific evidence can contribute to achieve a sustainable urban growth by helping to implement early conservation actions, such as limiting land use change, promoting green space within the city, as well as identifying focal conservation areas (Ortega-Álvarez \& MacGregor-Fors, 2009; lkin et al. 2015).

Most research on bird species richness in cities from the Southern Cone of South America has been conducted in temperate grasslands and Mediterranean forests. Global analyses on urban birds have found that studies in temperate regions dominate the literature, with lack of research from tropical forest 
regions (Chace \& Walsh 2006). In the Southern Cone, the focus on a few large cities has led to a gap of knowledge on different biomes. For instance, no studies were found in montane grasslands and shrublands and dessert and xeric shrublands. Given that the Southern Cone presents more than half of world terrestrial biomes (eight of 15 biomes, Henwood 1998), their cities provide an excellent opportunity to better understand biodiversity responses to urbanization in a variety of climates and geological conditions.

\section{Study design}

Short-term research dominates the literature. Ninety percent of studies lasted for one or two years, whereas only one study presented data for more than three years. The study with the longest duration ( 6 years of surveys, that comprised an extent of a decade) examined changes in the bird community in an urban wetland, and their possible associations with anthropogenic disturbance (Kusch et al. 2008). The lack of long-term research is common in ecological research and limits our understanding on ecosystems and human impacts in the long term (Turner et al. 2003). Long-term ecological studies are needed to understand the factors driving population, community and ecosystem change, and allow to undertake early actions to prevent species extinctions and rescue ecosystems from extinction cascades (Gaiser et al. 2020).

Most urban avian research was conducted in one season, where the reproductive season (spring and summer seasons) dominated the literature. Fewer studies comprised both reproductive and nonreproductive seasons. Studies that have included reproductive and non-reproductive seasons have found changes in species richness through the year (e.g. Fernández et al. 2009). This might be due to seasonal movements (e.g. migrations) in Neotropical birds as well as cities providing a wintering refuge during environmentally hard seasons (e.g. Fernández et al. 2009; Villaseñor \& Escobar, 2019). Given that patterns of species richness can change through the year in a city, it is important to consider these variations and possible changes in the influence of predictive variables on species richness.

Green areas were the preferred environment to conduct research. This pattern has been reported by authors from Latin America (MacGregor-Fors \& García-Arroyo 2017), although a recent literature review on avian abundance reported greater number of studies on the urban matrix (Leveau \& Zuria, 2017). Urban parks have received greater attention probably because their large area covered by vegetation maintains a high diversity of birds, allowing researchers to record a greater variety of species than builtup areas, which are commonly dominated by a few exotic species (e.g. Díaz \& Armesto 2003, Villaseñor et al. 2020). Informal green areas, such as vacant lands, have received limited attention, with only one study (a master science thesis) comparing bird species richness among vacant lands, urban parks and residential areas in Santiago de Chile (Chiang, 2019).

\section{Effect of predictive variables on species richness}

The effect of predictive variables on bird species richness in the Southern Cone agrees with common findings from the world. Vegetation cover and plant diversity exhibited mostly positive effects on bird species richness (Estades 1995, Urquiza \& Mella 2002, Leveau \& Leveau 2004), findings that agree with 
global research (Chace \& Walsh 2006, Evans et al. 2009, Beninde et al. 2015, Nielsen et al. 2014). Urban cover, such as built-up area and impervious surfaces, as well as human-disturbance, such as vehicle traffic, exhibited mainly negative effects on bird species richness (Germain et al. 2008). These findings are also consistent with previous literature reviews (e.g. Marzluff et al. 2001, Chace \& Walsh 2006, Beninde et al. 2015, MacGregor-Fors \& García-Arroyo 2017).

Most studies investigated the relationship between bird species richness and environmental variables. There was a clear knowledge gap: no study evaluated how socio-economics influences bird species richness in a city. Urban ecology must be considered as an interdisciplinary field, where social and natural science connect (Mclntyre et al. 2008). Different authors have found that variables associated to humans, such as cultural, economic and demographic variables influence biodiversity (Kinzig et al. 2005, Nilon et al. 2011; MacGregor-Fors \& Escobar-Ibáñez, 2017). Given the lack of studies exploring socioeconomic factors on birds, it is important to highlight that new urban ecology paradigms highlight to not only consider biological and environmental components, but rather a holistic view of urban ecosystems. For instance, the paradigm of "ecology for the city" encourages ecologists to work for a sustainable urban future with a variety of specialists with different backgrounds as well as with urban dwellers by aiming environmental integrity, social equity and economic viability (Pickett et al. 2016).

\section{Future research}

Our review evidence clear knowledge gaps that need to be addressed. Research that is urgently needed in the Southern Cone of South America includes studies performed in: (1) cities in biomes such as desserts, xeric shrublands, mountain grasslands and shrublands, flooded grasslands and savannas, and tropical grasslands, savannas and shrublands; (2) small and medium size cities, and urban areas that are experiencing rapid and unplanned urban growth; (3) long-term research as well those comprising different seasons across the year; (4) include green space other than urban parks; (5) interdisciplinary studies that consider environmental, social and economic components of urban ecosystems.

A problem for the future that emerges from our review is the lack of growth in studies published in the local language, because this is likely to increase the science-policy gap over time. Language barriers faced by Latin American scientists have limited their contribution in international journals, where scientists often declare to face difficulties in English witting, dissatisfaction and anxiety (Hanauer et al. 2019). However, this barrier might be lowering due to greater access to English education, training of scientists overseas and increasing international collaborations (Rodrigues et al. 2016). To ensure scientific evidence is available to local managers, urban planners, policy makers, and local communities, scientists should also disseminate their findings in their local language. This can be addressed by summarizing or synthetizing a compilation of findings from different studies to be published in local journals or magazines, writing books or book chapters, as well supervising thesis and making them publicly available. In this context, Universities should play an important role not only in generating local evidence but also in disseminate knowledge. Open-access journals led by Ornithological Associations of Chile and Argentina have greatly contributed to disseminating knowledge locally and should continue being a platform for urban ecological research. 
Urban ecology can provide data, principles, concepts, and tools to create livable and sustainable cities (Chace \& Walsh 2006). Therefore, it is necessary continue strengthen our knowledge of the factors influencing biodiversity to promote management, new public policies and development strategies for sustainable and biodiverse cities.

\section{Declarations}

Ethics approval and consent to participate: Not applicable.

Consent for publication: All authors consent to the publication of the manuscript in Urban Ecosystems, should the article be accepted by the Editor-in-Chief upon completion of the refereeing process.

Availability of data and materials: Data will be made available on request.

Competing interests: The authors declare that they have no conflict of interest.

Funding: Master in Wild Lands and Nature Conservation (Faculty of Forestry Sciences and Nature Conservation, Universidad de Chile) granted to CMP. ANID-FONDECYT 11201045 granted to NRV.

Authors' contributions: NRV conceived, designed, and wrote the manuscript. CMP collected and synthesized the data, elaborated graphs and figures and wrote the manuscript.

Acknowledgments: Authors thank scholarship from the Master in Wild Lands and Nature Conservation, from the Faculty of Forestry Sciences and Nature Conservation, Universidad de Chile, granted to CMP. NRV received funding from ANID-FONDECYT 11201045.

Authors' information: Catalina B. Muñoz-Pacheco \& Nélida R. Villaseñor*

Facultad de Ciencias Forestales y de la Conservación de la Naturaleza, Universidad de Chile, Santiago, 8820808, Chile.

*Corresponding author: Facultad de Ciencias Forestales y de la Conservación de la Naturaleza, Universidad de Chile, Santiago, 8820808, Chile.

Phone: +56 22 9785877. Email: villasenor@uchile.cl

ORCID: 0000-0001-8624-4484

\section{References}

Albers, C. (2019). Geografía Universal, Geosistemas Naturales, Biomas terrestres. Laboratorio de Geografía, Universidad de la Frontera. Recuperado en: http://labgeo.ufro.cl/catalogos/mundo.html 
Amaya-Espinel, J. D., Hostetler, M., Henríquez, C., \& Bonacic, C. (2019). The influence of building density on Neotropical bird communities found in small urban parks. Landscape and Urban Planning, 190, 103578.

Aronson, M. F., La Sorte, F. A., Nilon, C. H., Katti, M., Goddard, M. A., Lepczyk, C. A., ... \& Dobbs, C. (2014). A global analysis of the impacts of urbanization on bird and plant diversity reveals key anthropogenic drivers. Proceedings of the royal society B: biological sciences, 281(1780), 20133330.

Beninde, J., Veith, M., \& Hochkirch, A. (2015). Biodiversity in cities needs space: a meta-analysis of factors determining intra-urban biodiversity variation. Ecology letters, 18(6), 581-592.

Celis-Diez, J., Muñoz, C., Abades, S., Marquet, P., Armesto, J. (2017). Biocultural homogenization in urban settings: public knowledge of birds in City parks of Santiago, Chile. Sustainability. 9:485.

Chace, J.F. \& Walsh, J.J. (2006). Urban effects on native avifauna: a review. Landsc Urban Plan, 74:4669.

Chiang, L. (2019). Evaluación de sitios baldíos como espacios de conservación de aves nativas: el caso de Santiago de Chile (Evaluation of vacant sites as spaces for the conservation of native birds: the case of Santiago, Chile). Master Thesis (Doctoral dissertation, Master Thesis. Universidad de Chile, Santiago, Chile).

Díaz, I. A., \& Armesto, J. J. (2003). La conservación de las aves silvestres en ambientes urbanos de Santiago. Ambiente y Desarrollo, 19(2), 31-38.

Escobar-Ibáñez, J. F. \& MacGregor-Fors, I. (2017). Chapter 2: What's New? An Updated Review of Avian Ecology in Urban Latin America. In: MacGregor-Fors, I., \& Escobar-Ibáñez, J. F. (Eds.). (2017). Avian ecology in Latin American cityscapes. Springer.

Estades, C. F. (1995). Aves y vegetación urbana, el caso de las plazas. Boletín chileno de Ornitología, 2, 713.

Evans, K. L., Newson, S. E., \& Gaston, K. J. (2009). Habitat influences on urban avian assemblages. Ibis, 151(1), 19-39.

Falagas, M. E., Pitsouni, E. I., Malietzis, G. A., \& Pappas, G. (2008). Comparison of PubMed, Scopus, web of science, and Google scholar: strengths and weaknesses. The FASEB journal, 22(2), 338-342.

Farinha-Marques, P., Lameiras, J. M., Fernandes, C., Silva, S., \& Guilherme, F. (2011). Urban biodiversity: a review of current concepts and contributions to multidisciplinary approaches. Innovation: The European Journal of Social Science Research, 24(3), 247-271.

Fernández, B., Zulma, J., \& Antelo, C. M. (2009). Composición y variaciones estacionales de la avifauna en un ambiente antropizado (San Pablo, Tucumán, Argentina). Acta zoológica lilloana, 98-107. 
Gaiser, E. E., Bell, D. M., Castorani, M. C., Childers, D. L., Groffman, P. M., Jackson, C. R., Kominoski, J. S., Peters, D. P. C., Pickett, S. T. A., Ripplinger, J., \& Zinnert, J. C. (2020). Long-term ecological research and evolving frameworks of disturbance ecology. BioScience, 70(2), 141-156.

Garaffa, P. I., Filloy, J., \& Bellocq, M. I. (2009). Bird community responses along urban-rural gradients: does the size of the urbanized area matter?. Landscape and urban planning, 90(1-2), 33-41.

Germain, P., Cuevas, Y. A., Sanhueza, C. D. C., Tizón, F. R., Loydi, A., de Villalobos, A. E., ... \& Piován, M. J. (2008). Ensamble de aves en zonas con diferente grado de urbanización en la ciudad de Bahía.

BioScriba; 12, 35-45

González, I. F., Urrútia, G., \& Alonso-Coello, P. (2011). Revisiones sistemáticas y metaanálisis: bases conceptuales e interpretación. Revista española de cardiología, 64(8), 688-696.

Grimm, N. B., Faeth, S. H., Golubiewski, N. E., Redman, C. L., Wu, J., Bai, X., \& Briggs, J. M. (2008). Global change and the ecology of cities. Science, 319(5864), 756-760.

Hanauer, D. I., Sheridan, C. L., \& Englander, K. (2019). Linguistic injustice in the writing of research articles in English as a second language: Data from Taiwanese and Mexican researchers. Written Communication, 36(1), 136-154.

Harzing, A. W. (2010). The publish or perish book. Tarma Software Research Pty Limited.

Henwood, W. D. (1998). Editorial-the world's temperate grasslands: a beleaguered biome. Parks, 8(3), 1-2.

Hoekstra JM, Molnar JL, Jennings M, Revenga C, Spalding MD, Boucher TM, Robertson JC, Heibel TJ, Ellison K (2010) The Atlas of Global Conservation: Changes, Challenges, and Opportunities to Make a Difference (ed. Molnar JL). Berkeley: University of California Press.

Ibarguchi, G. (2014). From Southern Cone arid lands, across Atacama, to the Altiplano: biodiversity and conservation at the ends of the world. Biodiversity, 15(4), 255-264.

Ikin K., Le Roux D., Rayner L., Villasenor N., Eyles K., Gibbons P., Manning A., Lindenmayer D. (2015). Key lessons for achieving biodiversity-sensitive cities and towns. Ecological Management \& Restoration, 16 (3): 206-214.

Kinzig, A. P., Warren, P., Martin, C., Hope, D., \& Katti, M. (2005). The effects of human socioeconomic status and cultural characteristics on urban patterns of biodiversity. Ecology and Society, 10(1).

Kusch, A., Cárcamo, J., \& Gómez, H. (2008). Aves acuáticas en el humedal urbano de tres puentes, Punta Arenas (53 S), Chile austral. In Anales del Instituto de la Patagonia (Vol. 36, No. 2, pp. 45-51). Universidad de Magallanes. 
Leveau, L. M., \& Leveau, C. M. (2004). Comunidades de aves en un gradiente urbano de la ciudad de Mar del Plata, Argentina. El Hornero, 19(1), 13-21.

Leveau, L. M., \& Zuria, I. (2017). Flocking the city: Avian demography and population dynamics in urban Latin America. In Avian ecology in Latin American cityscapes (pp. 57-77). Springer, Cham.

MacGregor-Fors, I., \& Escobar-Ibáñez, J. F. (2017). Chapter 1: Birds from Urban Latin America, Where Economic Inequality and Urbanization Meet Biodiversity. In: MacGregor-Fors, I., \& Escobar-Ibáñez, J. F. (Eds.). (2017). Avian ecology in Latin American cityscapes. Springer.

MacGregor-Fors, I. \& García-Arroyo, M. (2017). Chapter 3: Birds from Urban Latin America, Where Economic Inequality and Urbanization Meet Biodiversity. In: MacGregor-Fors, I., \& Escobar-lbáñez, J. F. (Eds.). (2017). Avian ecology in Latin American cityscapes. Springer.

Magle, S. B., Hunt, V. M., Vernon, M., \& Crooks, K. R. (2012). Urban wildlife research: past, present, and future. Biological conservation, 155, 23-32.

Manterola, C., Astudillo, P., Arias, E., \& Claros, N. (2013). Revisiones sistemáticas de la literatura. Qué se debe saber acerca de ellas. Cirugía Española, 91(3), 149-155.

Marzluff, J.M., Bowman, R., \& Donnelly, R. (2001). A historical perspective on urban bird research: trends, terms, and approaches. In: Marzluff JM, Bowman R, Donnelly R (eds) Avian ecology and conservation in an urbanizing world. Springer, New York, pp 1-17

Mclntyre, N. E., Knowles-Yanez, K., \& Hope, D. (2008). Urban ecology as an interdisciplinary field: differences in the use of "urban" between the social and natural sciences. Urban ecology (pp. 49-65). Springer, Boston, MA.

McKinney, M. L. (2008). Effects of urbanization on species richness: a review of plants and animals. Urban ecosystems, 11(2), 161-176.

McKinney, M. L. (2002). Urbanization, Biodiversity, and ConservationThe impacts of urbanization on native species are poorly studied, but educating a highly urbanized human population about these impacts can greatly improve species conservation in all ecosystems. Bioscience, 52(10), 883-890.

Mittermeier, R. A., Turner, W. R., Larsen, F. W., Brooks, T. M., \& Gascon, C. (2011). Global biodiversity conservation: the critical role of hotspots. In Biodiversity hotspots (pp. 3-22). Springer, Berlin, Heidelberg.

Ministerio del Medio Ambiente (MMA). (2018). Biodiversidad de Chile. Patrimonio y Desafíos. Tercera Edición. Tomo I, 430 páginas. Santiago de Chile.

Ministerio de Vivienda, Ordenamiento Territorial y Medio Ambiente, MVOTMA. 2014. V Informe Nacional a la Conferencia de las Partes del Convenio de Diversidad Biológica. República de Uruguay. 134 p. 
Muñoz-Pedreros, A., González-Urrutia, M., Encina-Montoya, F., \& Norambuena, H. V. (2018). Effects of vegetation strata and human disturbance on bird diversity in green areas in a city in southern Chile. Avian Research, 9(1), 38.

Neira, C. F., Farías, C. H., \& Hernández, V. S. (2011). Las revistas científicas latinoamericanas en el ISI Web of Science: una opción para académicos e investigadores. Serie Bibliotecología y Gestión de Información, (65), 1-30.

Nielsen, A. B., Van Den Bosch, M., Maruthaveeran, S., \& van den Bosch, C. K. (2014). Species richness in urban parks and its drivers: a review of empirical evidence. Urban ecosystems, 17(1), 305-327.

Nilon, C. H., Warren, P. S., \& Wolf, J. (2011). Baltimore birdscape study: identifying habitat and land-cover variables for an urban bird-monitoring project. Urban Habitats, 6(1).

Nuñez, M. A., Barlow, J., Cadotte, M., Lucas, K., Newton, E., Pettorelli, N., \& Stephens, P. A. (2019).

Assessing the uneven global distribution of readership, submissions and publications in applied ecology: obvious problems without obvious solutions. Journal of applied ecology., 56(1), 4-9.

Olson, D. M., Dinerstein, E., Wikramanayake, E. D., Burgess, N. D., Powell, G. V., Underwood, E. C., ... \& Loucks, C. J. (2001). Terrestrial Ecoregions of the World: A New Map of Life on EarthA new global map of terrestrial ecoregions provides an innovative tool for conserving biodiversity. BioScience, 51(11), 933-938.

Ortega-Álvarez, R., \& MacGregor-Fors, I. (2009). Living in the big city: Effects of urban land-use on bird community structure, diversity, and composition. Landscape and urban planning, 90(3-4), 189-195.

Ortega-Álvarez, R., \& MacGregor-Fors, I. (2011a). Spreading the word: the ecology of urban birds outside the United States, Canada, and Western Europe. The Auk, 128(2), 415-418.

Ortega-Álvarez, R., \& MacGregor-Fors, I. (2011b). Dusting-off the file: A review of knowledge on urban ornithology in Latin America. Landscape and Urban Planning, 101(1), 1-10.

Perepelizin, P. V., \& Faggi, A. M. (2009). Diversidad de aves en tres barrios de la ciudad de Buenos Aires, Argentina. Multequina, (18), 71-85.

Pickett, S. T., Cadenasso, M. L., Childers, D. L., McDonnell, M. J., \& Zhou, W. (2016). Evolution and future of urban ecological science: ecology in, of, and for the city. Ecosystem health and Sustainability, 2(7), e01229.

Pullin AS, Stewart GB (2006) Guidelines for systematic review in conservation and environmental management. Cons Biol 20:1647-1656

Rodrigues, M. L., Nimrichter, L., \& Cordero, R. J. (2016). The benefits of scientific mobility and international collaboration. FEMS microbiology letters, 363(21), fnw247. 
Secretaria de Ambiente y Desarrollo Sustentable, SAyDS. (2015). Quinto Informe Nacional para la Conferencia de las Partes del Convenio sobre la Diversidad Biológica (CBD). República Argentina. 97 p.

Silva, C. P., García, C. E., Estay, S. A., \& Barbosa, O. (2015). Bird richness and abundance in response to urban form in a Latin American city: Valdivia, Chile as a case study. PLoS One, 10(9), e0138120.

Turner, M. G., Collins, S. L., Lugo, A. L., Magnuson, J. J., Rupp, T. S., \& Swanson, F. J. (2003). Disturbance dynamics and ecological response: the contribution of long-term ecological research. BioScience, 53(1), 46-56.

United Nations. (2015). World population 2015. Population Division Department of Economic and Social Affairs United Nations, New York.

United Nations. (2019). Volume II: Demographic Profiles: World population prospects 2019: Highlights. Population Division Department of Economic and Social Affairs United Nations, New York.

UNDP (2010). América Latina y El Caribe: una superpotencia de biodiversidad. Un documento de Política. United Nations Development Programme.

Urquiza, A., \& Mella, J. (2002). Riqueza y diversidad de aves en parques de Santiago durante el período estival. Boletín Chileno de Ornitología, 9(1), 12-21.

Villaseñor, N. R., Chiang, L. A., Hernández, H. J., \& Escobar, M. A. (2020). Vacant lands as refuges for native birds: An opportunity for biodiversity conservation in cities. Urban Forestry \& Urban Greening, 49, 126632.

Villaseñor, N. R., \& Escobar, M. A. (2019). Cemeteries and biodiversity conservation in cities: how do landscape and patch-level attributes influence bird diversity in urban park cemeteries? Urban Ecosystems, 22(6), 1037-1046.

\section{Figures}




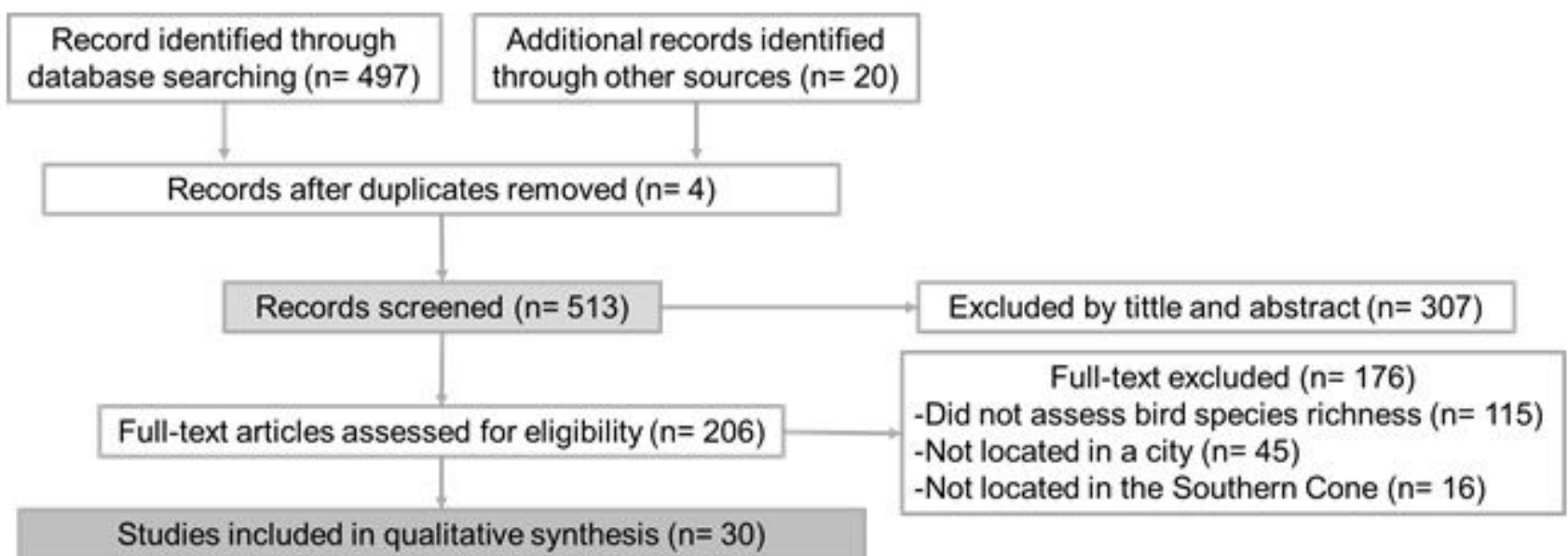

\section{Figure 1}

Literature search flow diagram.

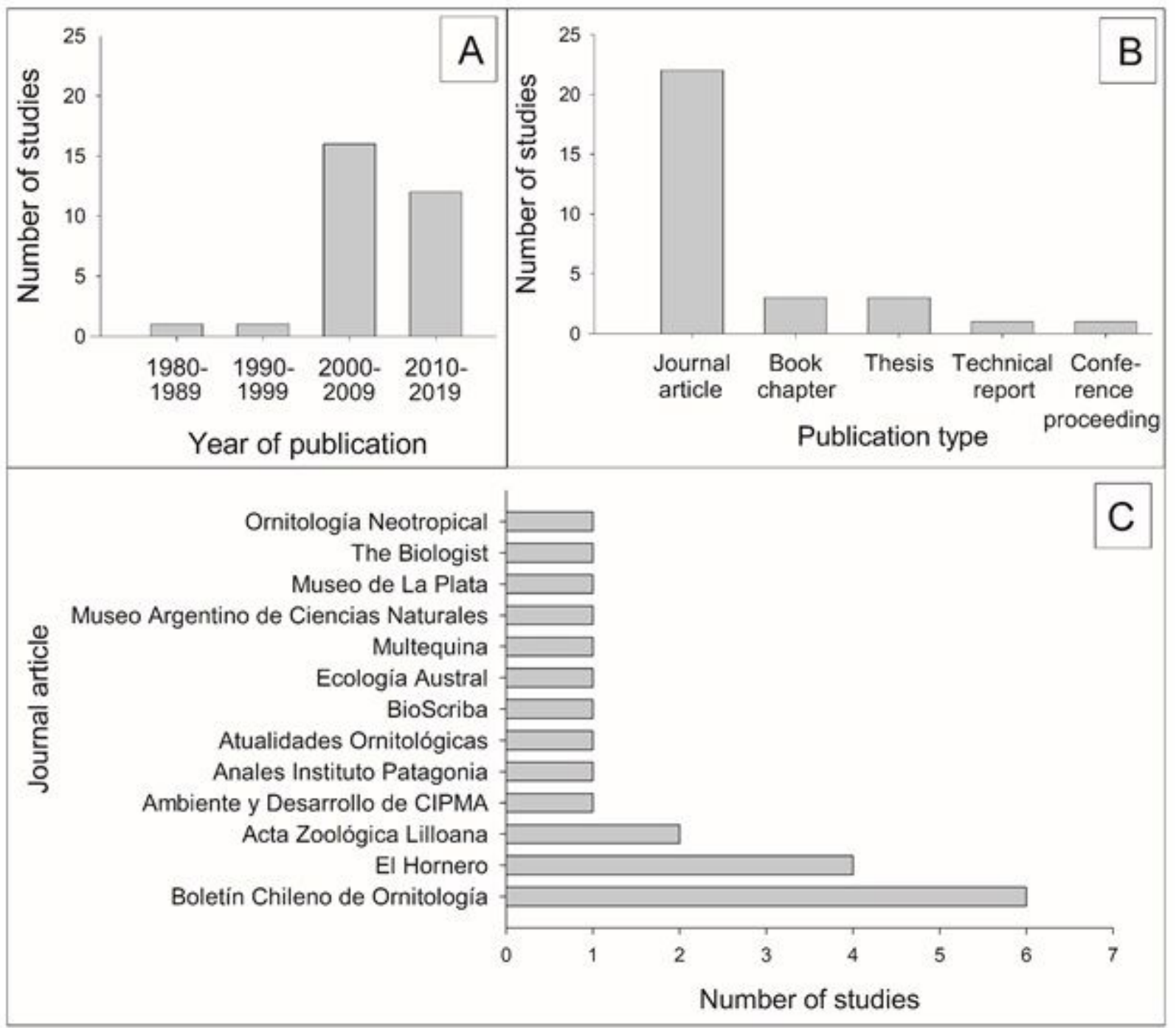


Figure 2

A. Number of studies by decade. B. Number of studies by type of publication. C. Number of studies per scientific journal.

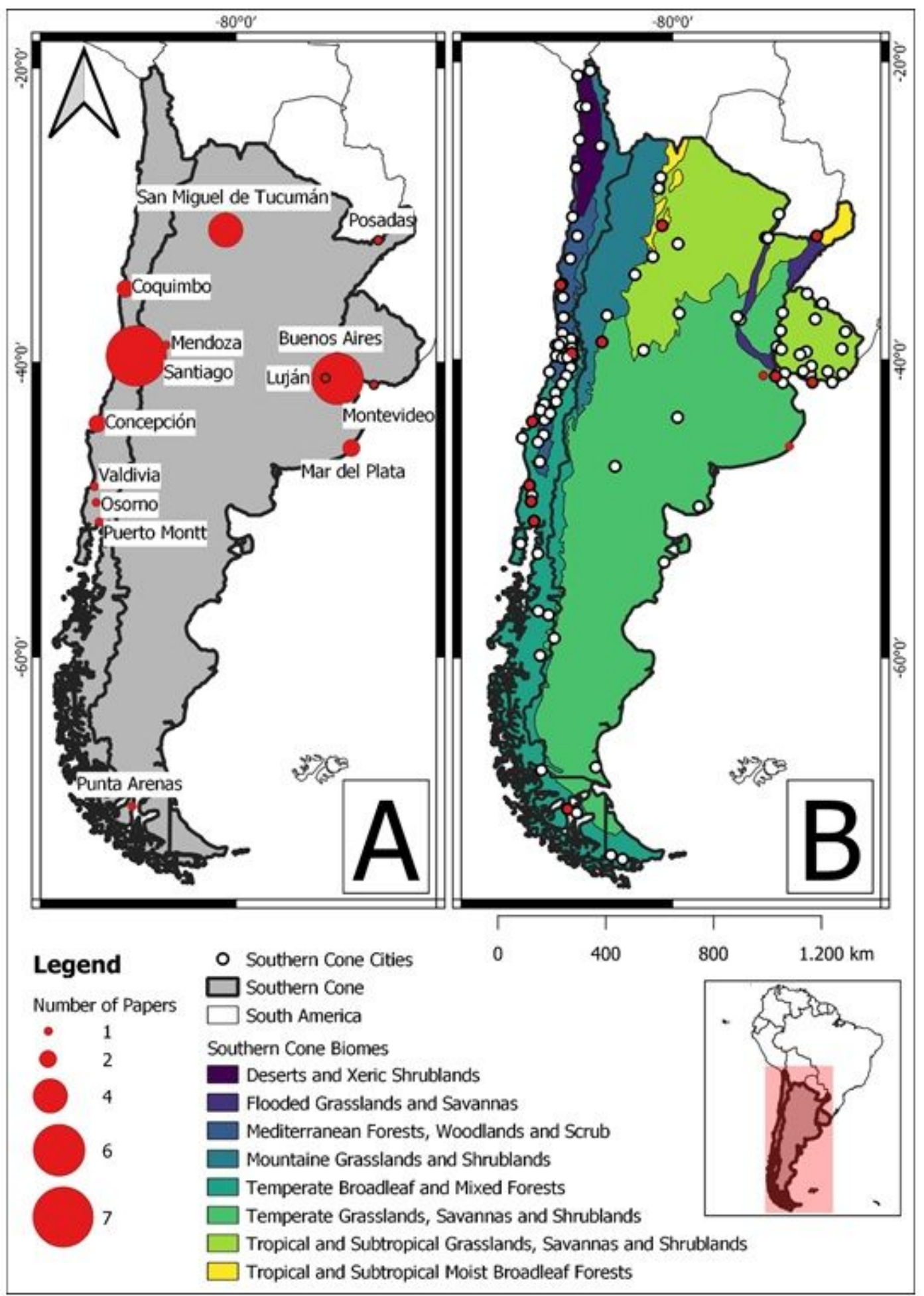

Figure 3 
A. Geographical representation of the number of studies by city in the Southern Cone. B. Cities from the Southern Cone with studies (red dots) and without studies (white dot) according to biomes.

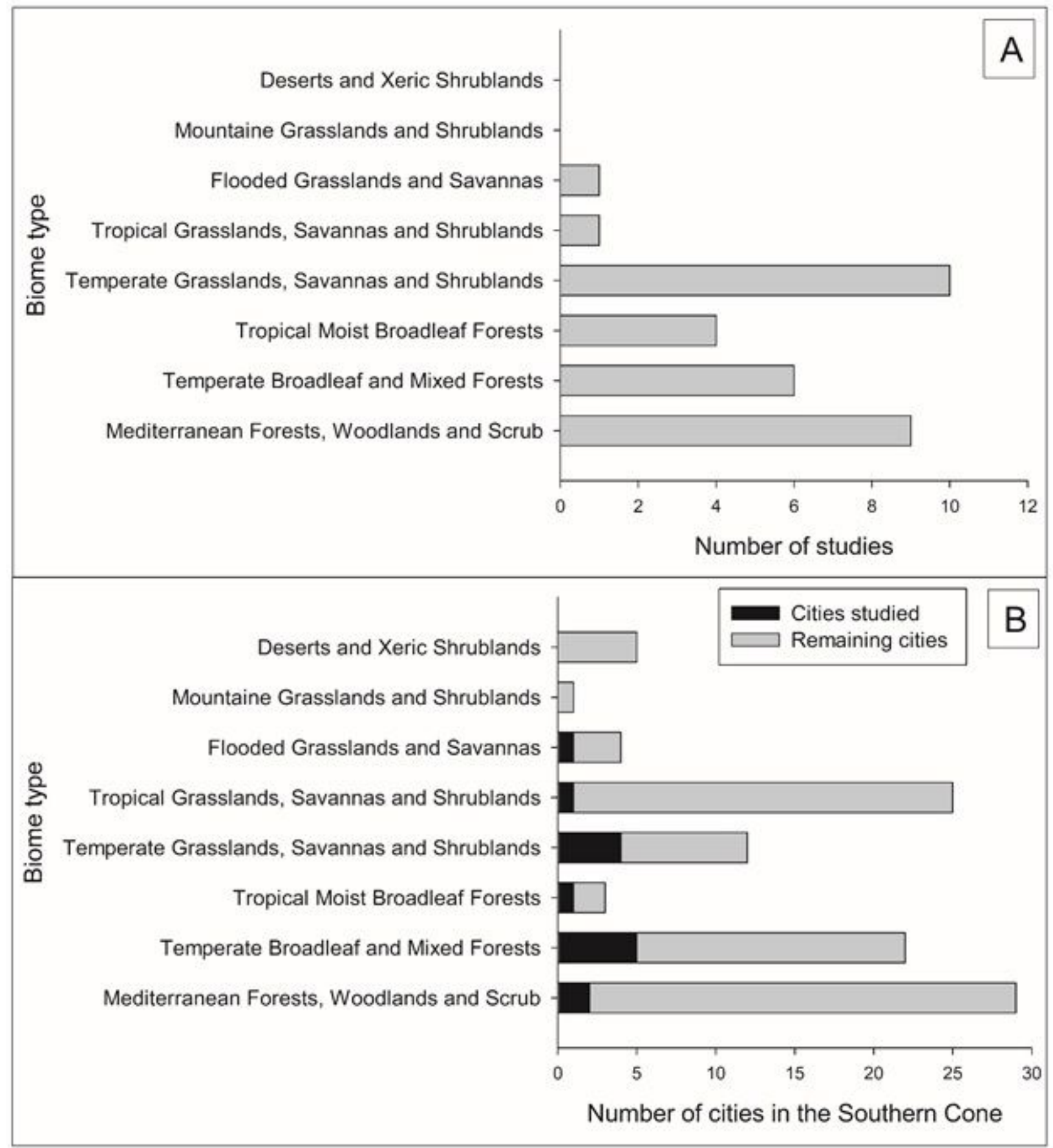

\section{Figure 4}

A. Number of studies by biome. B. Number of cities with and without studies by biome. 


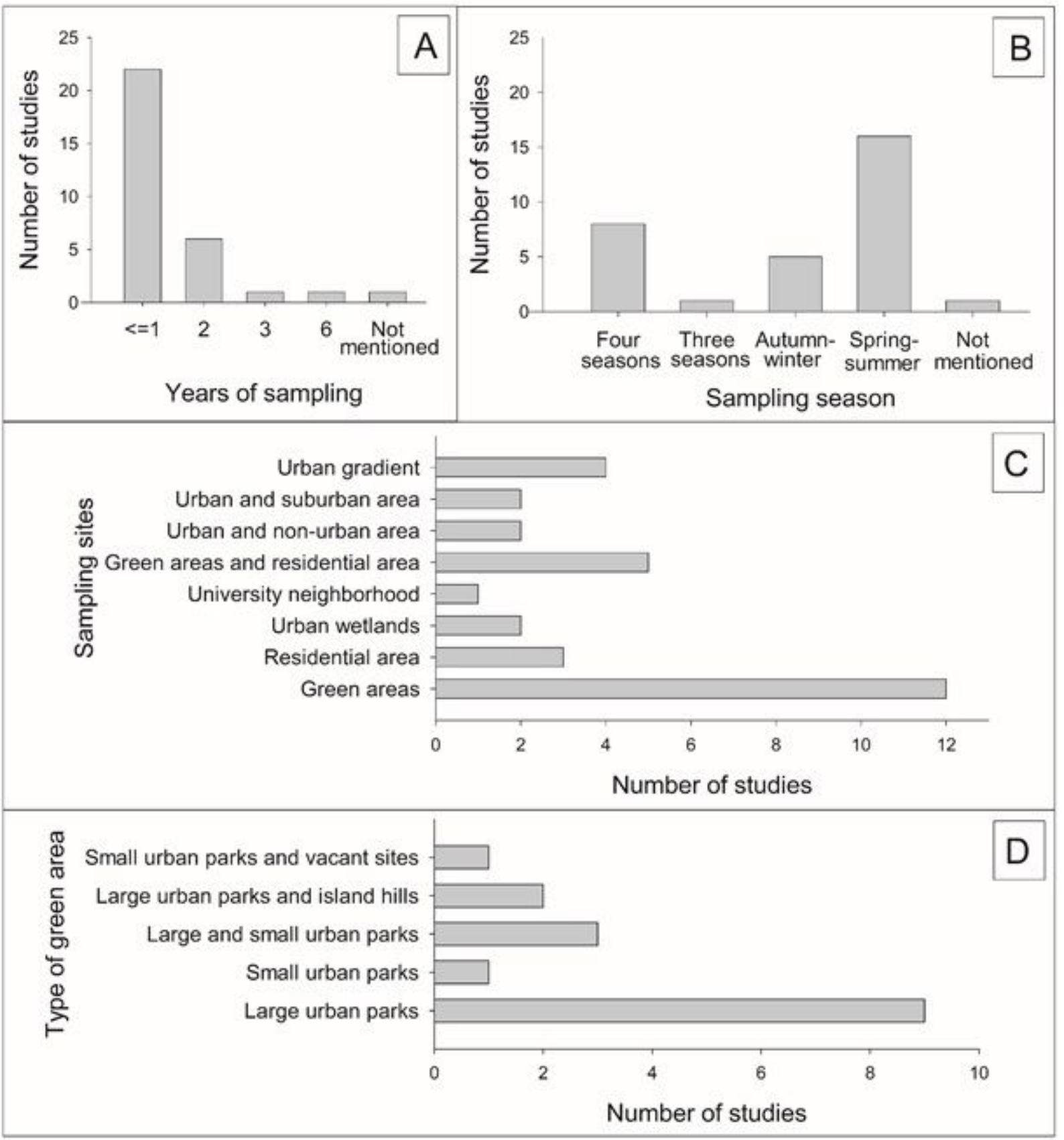

\section{Figure 5}

A. Number of studies according to sampling length (in years). B. Number of studies by sampling season. C. Number of studies according to the environment surveyed. D. Number of publications according to the type of green area sampled. 


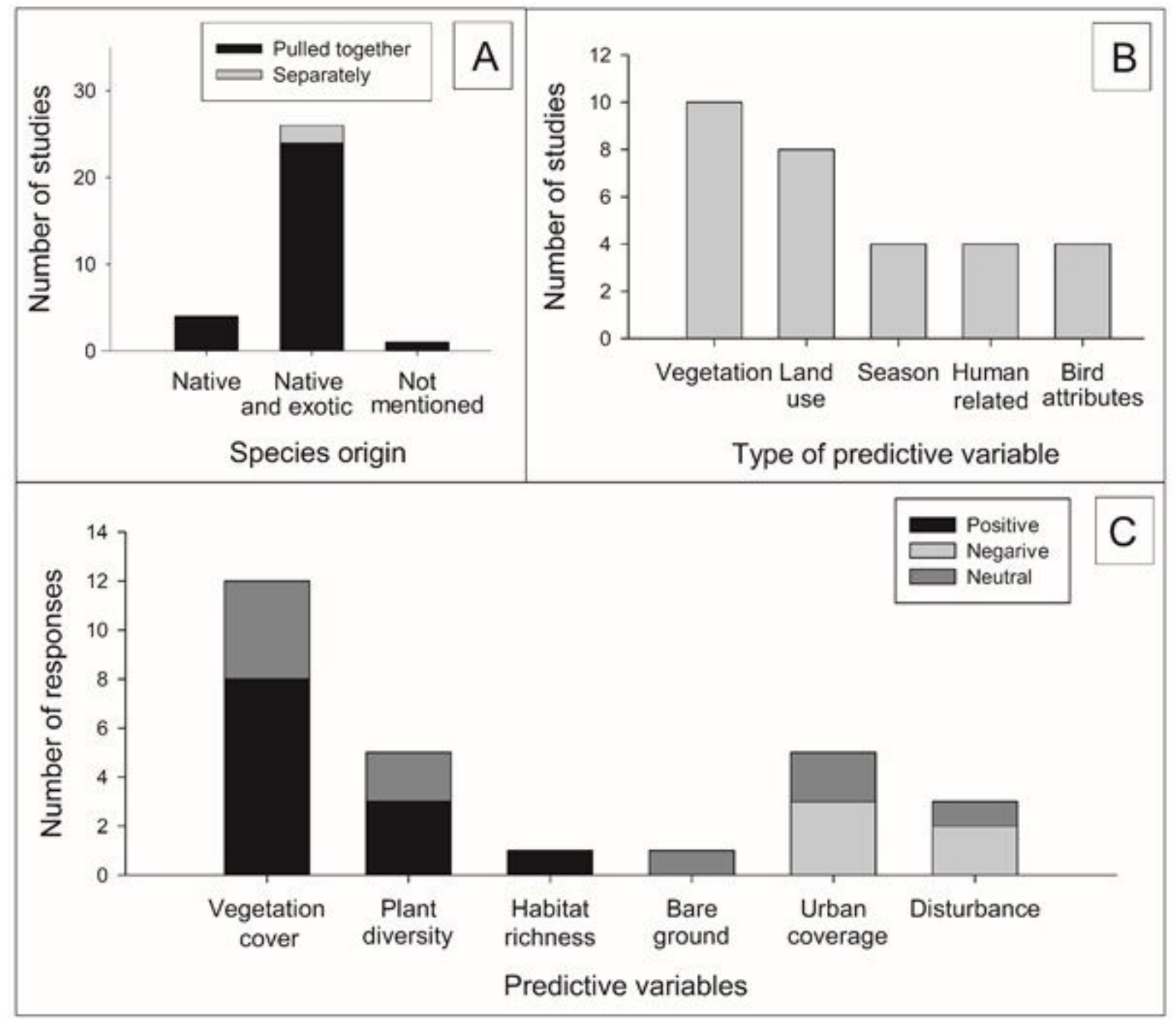

Figure 6

A. Number of publications according to the origin of birds considered in species richness. B. Number of studies according to the type of predictive variable analyzed. C. Effect (positive, negative or neutral) of predictive variables on bird species richness.

\section{Supplementary Files}

This is a list of supplementary files associated with this preprint. Click to download.

- Appendix.docx 